\title{
Incorporating creativity into teachers practice and self-concept of professional identity
}

Article

Accepted Version

Davies, T. (2013) Incorporating creativity into teachers practice and self-concept of professional identity. The Journal of Educational Change, 14 (1). pp. 51-71. ISSN 1573-1812 doi: https://doi.org/10.1007/s10833-012-9192-3 Available at https://centaur.reading.ac.uk/28046/

It is advisable to refer to the publisher's version if you intend to cite from the work. See Guidance on citing.

To link to this article DOI: http://dx.doi.org/10.1007/s10833-012-9192-3

Publisher: Springer

Publisher statement: The original publication is available at www.springerlink.com

All outputs in CentAUR are protected by Intellectual Property Rights law, including copyright law. Copyright and IPR is retained by the creators or other copyright holders. Terms and conditions for use of this material are defined in the End User Agreement.

www.reading.ac.uk/centaur 
Central Archive at the University of Reading

Reading's research outputs online 


\title{
Incorporating creativity into teachers practice and self-concept of professional identity
}

\begin{abstract}
The study explores what happens to teachers practice and 'professional identity when they adopt a collaborative action research approach to teaching and involve external creative partners and a university mentor. The teachers aim to nurture and develop the creative potential of their learners through empowering them to make decisions for themselves about their own progress and learning directions. The teachers worked creatively and collaboratively designing creative teaching and learning methods in support of pupils with language and communication difficulties. The respondents are from an English special school, primary school and girls secondary school. A mixed methods methodology is adopted.
\end{abstract}

Gains in teacher confidence and capability were identified in addition to shifts in values that impacted directly on their self-concept of what it is to be an effective teacher promoting effective learning. The development of their professional identities within a team ethos included them being able to make decisions about learning that are based on the educational potential of learners that they proved resulted in elevated standards achieved by this group of learners. They were able to justify their actions on established educational principles. Tensions however were revealed between what they perceived as their normal required professionalism imposed by external 
agencies and the enhanced professionalism experienced working through the project where they were able to integrate theory and practice.

Keywords: Teacher identity; teacher professionalism; teacher professionality; creative teaching; creative learning; creative potential; teacher collaboration; professional learning community.

\section{Introduction}

The terms profession and professional with regard to teaching and education are as much debated today as they have always been. Hoyle \& John (1995) present them as essentially contested concepts, hence notions of professional identity are linked to professional learning, personality traits and professionality. To maintain pace with fundamental shifts in local and global societies, it requires teachers themselves to be creative in the ways they conceive and carry out their role and in the ways they develop their key relationships with learners and other stakeholders.

Members of societies around the globe are recognising that creativity needs to be applied to education to respond to key changes and since the late 1990's is perceived to be central to education in a way it never has been before (Craft, 2005). Selzer \& Bentley (1999) in writing about 'The Creative Age' state that:

'we believe that the key challenge is to shift the focus away from what people should know and onto what they should be able to do with the knowledge. This is central to developing creative ability' (p. 25). 
To incorporate creativity into educational practice implies that teachers selfconcept of their professionalism will change. This type of change is incorporated into what Hoyle (1981) conceptualized as the notion of extended professionality where teachers are 'empowered to be responsive to their circumstances, to interpret goals more broadly and exercise creativity in their professional work and activity' (Davies, 2002, p. 49).

\section{The socio-cultural context for creative learning and teaching}

Schools as communities have many roles at many levels within society. Increasingly the ability of individuals to grasp informal educational opportunities is playing a role in the achievement of life success. Barak \& Doppelt (1998) note that:

\footnotetext{
'In the era of information explosion, change, dynamism and pluralism, there is an increased need for education to equip the school graduate with higher order cognitive skills. Future society may particularly reward those who not only possess logical thinking, critical thinking and problem-solving skills, but are also enterprising, innovative original and creative' (p. 1).
}

Handy (1995) posits the view that schools are concerned to prioritise the maintenance of cycles and structures, rather than moving towards the "new age', and are resistant to change. Consequently, schools can be uncomfortable places for creativity and innovation even though there are well recognised exceptions to the status quo. Judgments about the work of learners and teachers are made by many agencies, for example, educationalists, parents, government, industry and commerce and other lobbyists who interpret domains in ways that serve their own interests and value systems. Each makes judgments based on what they perceive to be in 
the best interests of the learners, in relation to their future roles as citizens and participants in complex communities and society as a whole. However, teachers are the mediators of learning in the settings of schools and classrooms.

Davies (2006) noted that teachers, in striving to balance the cultural pressures they perceived whilst striving to carry out their role, were fearful of making decisions that affected learners' lives and futures. This was until strong relationships were built with the learners and that they were in possession of a strong knowledge base about their complex and interwoven needs. Teachers therefore need high-level professional skills and knowledge in order to carry out their task:

'... if you trust teachers and they are properly trained to the highest level possible .... Their identity becomes so closely linked to the identity of the learners that in 'best practice' scenarios, performance of teachers and learners are inextricably linked' (Davies, 2006: p. 15).

Assessment-led approaches have been particularly restrictive in classrooms to the identities of both learners and teachers (Smyth, 2007). Even so, in England, projects such as Royal Society of Arts (RSA) sponsored 'Opening Minds' are currently striving to establish learning environments in classrooms that encourage the creative growth of individual pupils and staff in order that they should achieve their human potential (RSA, 2010). Bosher \& Hazlewood (2008) discuss a new form of professionalism that holds at its heart collegiate management and a distribution of power to all members of an educational community that permits the necessary risk-taking that can result in a creative climate and culture that forms the basis of a healthy 
professional learning community. This form of professionalism is consistent with developing the educational drive within schools necessary to contribute to what Hargreaves \& Shirley (2009) describe as the 'Fourth Way' which:

'brings together government policy, professional involvement and public engagement around an inspiring social and educational vision of prosperity, opportunity and creativity’ (p. 71)

Government policy however still remains out of step in England with such a vision.

The nature of teacher professionalism and professionality in the modern era

Goodson \& Hargreaves (1996, p. 4) refer directly to the lack of consensus that surrounds the debate on the nature of professionalism resulting from it being a concept that is socially and culturally constructed. Beck (2008) discusses in detail whether recent modern educational developments in the UK have been about re-professionalising or de-professionalising (pp. 119143) and that a political aim has been to create a compliant profession with the discourse of standards at the centre with the intention to marginalise or even silence competing ideas about educational development and reform ( $\mathrm{p}$. 138). Evans (2008) argues that a hallmark of the modern era in re-defining professionalism has been to set narrower more procedurally based boundaries for teachers (that can be argued has de-professionalised teachers). Frowe (2008, p. 49) believes that there has been an attempt to capture in a series of propositions something that cannot be exhaustively captured. 
A related area of debate centres on the quality of service given by professionals. Professionality is a term defined by Hoyle (1975) as 'the knowledge, skills and procedures that teachers use in their work' (p. 138). He recognises and defines extended professionality as when teachers are empowered within the context of their professionalism. His notion of restricted professionality is when teachers' judgment-making is limited and undertaken by other agencies on their behalf, usually those with policymaking power.

Aubusson et. al. (2008) recognise how important close nurturing is to generate and maintain professional learning communities in education ( $\mathrm{p}$. 134) for which teacher learning is central coupled with teacher research. They describe how action learning that places an emphasis on inquiry-led action can help schools build the capacity to improve. In order to do this however, teachers need to understand deeply the pervading culture within the classroom. Craft (2005) considers the importance of teachers as educators striving to understand the social contexts that gives rise to different values that in turn impact upon the ways we choose to facilitate learner participation and creativity (pp. 95-97). Such an approach can stimulate and contribute to sustainable change over time resulting in largescale shifts in values and attitudes.

\section{Building learning cultures through creativity in education}

The social and economic cultures in which individuals work, in addition to the psychological factors, play an important role in the recognition of 
creative contributions to any field Csikzentmihalyi (in Feldman, et.al., 1995). Concepts linked to the creative potential of 'ordinary people' are explored by researchers such as Craft (2005) \& Fryer (1996). Each of the authors recognise that there are disadvantages as well as advantages to promoting creativity in schools and they elaborate many of these.

As a result of this growing recognition, a number of authors have engaged in the process of promoting creativity. LeBoeuf (1994) re-published his book on promoting creative thinking. De Bono defines lateral thinking as a means to change concepts and perception and his 'thinking hats' tool was devised as a method of achieving this in social and cultural settings. He suggests that creative thinking strongly overlaps with this in that it is concerned with creating new concepts and / or new perceptions (1992, pp. 52-56; De Bono, 2010). He argues convincingly and methodically that creativity can be taught if attitudes are appropriate (p. 239).

There is much debate about the value and type of testing that is appropriate when creative learning is taking place exemplified by the arguments presented by Rogers \& Fasciato (2005). Shouksmith (1970) discusses the high levels of understanding required to interpret any kind of creativity testing, stressing freedom from restriction as a basis for creative production. He notes that Torrance (1962), who developed extensive methods for testing creativity never intended that (his) tests should be regarded as composite measures reflecting all aspects of creativity (p. 200). In England, the culture of high stakes testing has distorted perceptions about the methods and values 
associated with different types of testing procedure. In the NACCCE report of (1999) key recommendations were made to include more emphasis on formative assessment and to ensure that assessment was appropriate including that relating to creativity (pp. 169-170).

Three schools - a girls secondary school, a special needs school and a primary school won a bid to conduct a collaborative project under the auspices of the 'Creativity and Action Research Awards Two' (CARA2) projects managed by CapeUK (2006). The schools viewed the project as an opportunity to explore new approaches to teaching and learning that placed emphasis on creativity, in particular giving teachers the opportunity to think through carefully developed teaching methodologies that suited the needs of the learners and that were theoretically underpinned by literature. The research reported investigates how this was done and the major impacts upon teacher professionalism.

Each school was represented by a co-ordinator who were participants in the research, Participants A, B and C. The project focus was the application of De Bono's Thinking Hats (1985) to the use of dance as a medium for creative learning with pupils whose linguistic capabilities were very limited. The title of the project evolved over the period of the project through collaboration with the partners into: "Body Talk: using movement to unlock the creative potential in children with speech and language difficulties". 
The project enabled the teachers group to identify, invite and work with external creative partners and a university mentor as a critical friend. The teachers decided to develop a formative assessment tool using literature to inform practice and involved reflection upon their own practice. During the process, the professional identities of the teachers evolved as they focused ever more closely on personalised approaches to learning and empowering learners through sharing the responsibility for learning with them, together with each other, the creative partner and the mentor.

The project was undertaken with eighteen pupils, six from each of the three schools involved. The pupils ranged in age from eight - fourteen years and all had varying degrees of speech and language difficulties. The project ran for a school term with a total of ten, two-hour workshops.

The teachers' group began by aiming to be able to identify childrens' creative responses and relate them to de Bono's six expressed modes of thinking using dance as the medium for teaching and learning. They subsequently demonstrated ways of broadening, clarifying or simplifying creative decision-making and behaviour. The approach adopted by the team was to engage in the processes of ideation, action and reflection in holistic, iterative ways as they struggled:

- To establish a way of assessing childrens' creativity through dance.

- To use assessment data to plan interventions that will broaden what children are able to bring to creative activities. 
- To engender a sense of belonging to a creative community for the adults and children involved.

They became interested in how to incorporate in the classroom such elements as: the creative pause - a willingness to stop and think; challenge not criticism but a belief that there are better ways of solving a problem; green hat - looking for alternatives; listening - gaining tuned judgment helping others to realise creative potential; sensitisation - paying attention to possible instances of creativity; and others.

\section{Teacher participants}

\begin{tabular}{|l|l|l|l|}
\hline & Participant A & Participant B & Participant C \\
\hline $\begin{array}{l}\text { Type of school } \\
\text { taught in }\end{array}$ & Special Needs & Primary mainstream & $\begin{array}{l}\text { Secondary } \\
\text { mainstream }\end{array}$ \\
\hline $\begin{array}{l}\text { Level of } \\
\text { responsibility }\end{array}$ & $\begin{array}{l}\text { Class teacher; dance } \\
\text { specialist }\end{array}$ & Deputy headteacher & Dance teacher \\
\hline $\begin{array}{l}\text { Specialisms in } \\
\text { education }\end{array}$ & $\begin{array}{l}\text { Dance; special } \\
\text { educational needs }\end{array}$ & $\begin{array}{l}\text { Literacy; special } \\
\text { educational needs; } \\
\text { design and } \\
\text { technology }\end{array}$ & Dance; PE \\
\hline $\begin{array}{l}\text { Background in } \\
\text { education }\end{array}$ & $\begin{array}{l}\text { Dance; psychology; } \\
\text { secondary teacher }\end{array}$ & $\begin{array}{l}\text { Nursery teacher; } \\
\text { primary teacher; } \\
\text { local authority } \\
\text { adviser }\end{array}$ & Dance; PE \\
\hline $\begin{array}{l}\text { Number of years in } \\
\text { teaching }\end{array}$ & 6 & 21 & 3 \\
\hline
\end{tabular}

Research participant biographies

The teachers' group developed new methods and instruments in support of formative assessment and in so doing, enhancing the creative potential of the teachers involved. The motivation for the research challenge was to find a way to critically establish what had happened to the participants during the 
project and in particular: "what were the implications of creative teaching and learning on their teacher identity and ideas of professionalism.'

\section{Research hypothesis}

That when teachers are creative in their work with learners and use action research as an approach to curriculum development, it enhances their professionalism and shifts their identity in a way that resonates with Hoyle's (1981) notion of extended professionality consistent with the empowerment of teachers.

\section{Methods of data collection}

The strength of the curriculum project was that it has generated new theory and changed practice through the vision of the CARA2 project that promoted an 'action research' approach to the development of creativity in schools (CapeUK, 2005). The purpose of the project being to gain insights into:

\footnotetext{
'What it means for young people to be creative; what teachers and external partners actually do to encourage and develop creativity; how the setting and focus of learning affects creativity' (CapeUK, 2006: p. 20)
}

The challenge for the research design was to generate data that are likely to have sufficient depth and reflect the full range of contexts in which participants operated led to an early decision to adopt a mixed methods approach incorporating a variety of data collection techniques. A case study represented the heart of the design defined by Newby (2010: p. 618) as a 
bounded system developed over a period in time during which qualitative data is collected, that is rich in context and that involves a wide range of sources for obtaining information. It is to understand why what actually happened, happened. The data was collected using the following research instruments:

Part 1: A focus group discussion based around twelve key questions about perceptions of the nature and purposes of teaching and learning where participants shared their thoughts and feelings about project gains and how it had affected their understanding of their professionalism.

Part 2: A two-part questionnaire for participants to self - assess changes perceptions of change in their professionalism that occurred as a result of the project.

Part 3: An analysis of the final project report that was jointly compiled by the project participants.

The conditions set by Cresswell (1998, p. 63), for ensuring the worthwhileness and completeness of a case study were cross-referenced including clarity of boundaries, access to depth of information and terms of reference for data-gathering. Yin (1989, p. 54) re-enforces both the importance of the context dependency of case studies and that any generalisability needs to take into account the particular constraints of the case or cases. The major object for data analysis was that as Cresswell (1998) advises: '...it is a matter of pulling data apart then putting it back together again' (sic) ( p. 154). 
Yin (1989, pp. 146 - 151) records the following conditions for an exemplary case study for which this study is tested:

- Significance - a basis for the phenomena to be examined must be assured;

- Completeness - exhaustive efforts on the part of the researcher must be proved to uncover the available evidence;

- $\quad$ sufficiency - the evidence must be present for readers to reach independent judgments about the phenomena;

- engaging style - the report should be written in such a way as to be sufficiently compelling and seductive for the reader.'

It is important for the voices of the participants to reach the audience as this is important to all of the above. It should also allow for a range of alternative explanations and conclusions to be drawn, backed up by reference to evidence. The research instruments are now described in detail:

\section{Part 1 - focus group discussion}

A structured focus group interview involving all three school participants was recorded that required participants to discuss core areas of professional competence that were designed to cover major aspects of a teaching role. A qualitative analysis of the focus group discussion draws out what the participants' stated ideas are about, what they believe ought to happen with effective teaching and its impact upon learning. Finally, perceptions of the role of the learner in the learning process. Video was used for data gathering in the focus group for three main reasons: a) to contribute to dissemination for professional development purposes; $b$ ) to provide a data-set that could be 
analysed at different levels for research purposes; c) to provide an accurate record that could be interrogated to independently to verify development and research findings and reflections. The questions developed for the focus group were derived from the research findings in Davies (2006) evaluating creative teaching and learning in Europe and Craft, (2005) in her discussion of pedagogical strategies for creativity (pp. 41-50).

The focus group discussion was constructed around the questions like:

Q1 What is the role of a teacher in a classroom?

Q2 What are teachers preparing learners for? (Table 2)

\section{Part 2 - the questionnaire}

A questionnaire was designed that required participants to self-assess changes in their professional capacities from before, to after project completion. Following on from the recorded discussion, participants were asked to quantify their experience as teachers and complete values grids that recorded shifts in their beliefs about the role of the teacher (Table 2-T2) and attitudes of learners (Table $3-\mathrm{T} 3$ ). The elements used in these tables were developed by Davies (2002) as characteristics of creative teaching (T2) and opportunities for learner creativity (T3). These show some consistency with the way in which Jeffrey \& Craft (2004) \& Woods (2002) theorise the relationships between teaching for creative learning, creative teaching and creative learning. It was also ensured that participants had brought their responses to the fore in a complete and open way. 
The responses of the participants summarised what they felt had been the real impact of the study upon their actual teaching. The results for each category are cross-referenced and examined in the light of the research hypotheses. The responses have been analysed in relation to the contextual profile of the participants.

\section{Part 3 - the final report}

An analysis of the final project report that records the voices of the participants on how they summatively recorded the gains they felt were made and how these impacted upon their professionalism in reflection to their normal work in school.

\section{Data Analysis}

There are four major categories of data that make up the case study profile:

1. The focus group recorded discussion - the transcripts were coded and major themes drawn from the data relating to the research hypothesis included in Table 2.

2. The two-part questionnaire that surveyed participants' perceptions of shifts in emphasis in the teaching and learning that resulted from the participants' self- evaluation of the work in schools.

3. An analysis of the participants summative report that records detailed reflections on the impact of project methods; engagement in creative activities by participants and learners.

4. The participants' responses were cross-referenced with their biographies in Table 1. 
5. Finally, responses from each category were cross - referenced to seek any evidence of relationships between creativity in education and teacher identity.

\section{Results}

\section{Focus Group Discussion}

The question grid summarised in Table 2 consists of a summary of the responses of participants during the focus group interview supported by direct quotations from the participants.

Responses to focus group questions 


\begin{tabular}{|c|c|c|}
\hline $\begin{array}{l}\text { Question } \\
\text { number }\end{array}$ & Question discussed & Keywords and phrases used \\
\hline 1 & $\begin{array}{l}\text { What is the role of a teacher in a } \\
\text { classroom? }\end{array}$ & $\begin{array}{l}\text { Able to observe; flexible; enabling the learning; } \\
\text { teacher and learner together as equals; pupils feel the } \\
\text { teacher is also learning; reflecting with learners } \\
\text { creating learning potential; children can teach you }\end{array}$ \\
\hline 2 & $\begin{array}{l}\text { What are teachers preparing } \\
\text { learners for? }\end{array}$ & $\begin{array}{l}\text { Preparing for life; good self-esteem; take their own } \\
\text { lessons; independent; sense of own agency; work in a } \\
\text { range of contexts; things not easily assessable; taking } \\
\text { and managing power; being innovative }\end{array}$ \\
\hline 3 & $\begin{array}{l}\text { What types of relationships should } \\
\text { a teacher aim to build with their } \\
\text { students? }\end{array}$ & $\begin{array}{l}\text { Caring and secure environment; manage 'negative } \\
\text { energy' release; clear expectations; clear focus on } \\
\text { learning; freedom within clear boundaries; managing } \\
\text { our emotions }\end{array}$ \\
\hline 4 & $\begin{array}{l}\text { How does a teacher get the best } \\
\text { from their students? }\end{array}$ & $\begin{array}{l}\text { Being emotionally open; going through good and bad } \\
\text { times together; knowing your pupils; engage with } \\
\text { children as they are at the moment; small steps for } \\
\text { everyone }\end{array}$ \\
\hline 5 & $\begin{array}{l}\text { What types of personal qualities } \\
\text { are best suited to a teacher's role? }\end{array}$ & $\begin{array}{l}\text { Empathetic; listen and learn about the children; reflect } \\
\text { on what you find; be reflective about yourself }\end{array}$ \\
\hline 6 & $\begin{array}{l}\text { How can teachers work most } \\
\text { effectively together to obtain the } \\
\text { best for their students? }\end{array}$ & $\begin{array}{l}\text { Seeing how each other works; open professional non- } \\
\text { judgemental dialogue; gain vocabulary together; be } \\
\text { supportive; accept that others might not share values } \\
\text { or objectives; reflect together }\end{array}$ \\
\hline 7 & $\begin{array}{l}\text { How should teachers approach the } \\
\text { task of selecting the best teaching } \\
\text { approaches and curriculum for } \\
\text { students? }\end{array}$ & $\begin{array}{l}\text { Meet the needs of pupils; lack of freedom is currently } \\
\text { a problem to make the curriculum relevant and } \\
\text { meaningful; engage children in curriculum planning; } \\
\text { be flexible; draw on their strengths and interests }\end{array}$ \\
\hline 8 & $\begin{array}{l}\text { What should be the role of learners } \\
\text { in classrooms? }\end{array}$ & $\begin{array}{l}\text { Enable responsibility for pupils; enable them to be } \\
\text { accountable for their own learning; being responsible } \\
\text { for each others learning; teachers are role models for } \\
\text { pupils }\end{array}$ \\
\hline 9 & $\begin{array}{l}\text { How do we best measure what } \\
\text { students achieve in classrooms? }\end{array}$ & $\begin{array}{l}\text { Identifying and supporting pupil strengths; balancing } \\
\text { qualitative and quantitative approaches; assessment } \\
\text { needs to developmental more than 'high stakes' } \\
\text { summative }\end{array}$ \\
\hline 10 & $\begin{array}{l}\text { Is it possible for us as teachers to } \\
\text { account for the learning our } \\
\text { students achieve from other } \\
\text { people and other situations? }\end{array}$ & $\begin{array}{l}\text { Teachers cannot define success criteria for everything } \\
\text { taught; the emphasis on different types of assessment } \\
\text { is key; giving permission for pupils to take risks; } \\
\text { helping pupils with skill development; giving pupils } \\
\text { the confidence to ask questions }\end{array}$ \\
\hline 11 & $\begin{array}{l}\text { What responsibilities do students } \\
\text { have, and should have for their } \\
\text { own learning in } \\
\text { schools? }\end{array}$ & $\begin{array}{l}\text { Create the opportunities for pupils to behave like } \\
\text { teachers and they will take the same responsibilities; } \\
\text { asking pupils how their partners are rather than how } \\
\text { they are; managing carefully the 'release of } \\
\text { responsibility and power' to the pupils; self-selecting } \\
\text { learning groups }\end{array}$ \\
\hline 12 & $\begin{array}{l}\text { What factors limit the achievement } \\
\text { of students in schools and in } \\
\text { society? }\end{array}$ & $\begin{array}{l}\text { If pupils are not allowed to 'follow through' their } \\
\text { projects; if they are not encouraged to innovate and } \\
\text { this is not celebrated and shared; expectations that are } \\
\text { too low or badly managed learning steps; teachers } \\
\text { limit children with pre-conceived ideas; pupils always } \\
\text { have the ability to shock with what they can do }\end{array}$ \\
\hline
\end{tabular}


The energy and enthusiasm of the participants was obvious throughout the project. Was this because their hard to reach pupils made such clear and obvious strides in their learning? Or was it the novelty of working in a project?

'Participant A - we cannot tick a box and show clearly what it has been but we have seen children blossom...I think seeing the children- from being very passive in the first few sessions - waiting for us really - to becoming quite forceful in the last few sessions.'

The discussion of what ought to happen in classrooms was thoughtful and idealistic focusing in direct ways on the importance of responding to the cognitive and emotional needs of individual learners; sharing power with learners; helping learners to build experience of taking responsibility and not being formulaic in their role as teachers. These being achieved through working closely with learners to support them in understanding the relationship between exercising freedom and taking essential responsibilities in situated learning settings.

'Particpant $\mathrm{C}$ - I see the teacher in the classroom as someone who is enabling the learning but sharing in the learning themselves as well. The best sort of learning happens when you have the teacher and the pupils coming together as learners as some sort of equals...'

Expressions of what the participants believed ought to be their role, was communicated carefully and thoughtfully. As professionals, the importance of living the moment is stressed, being open, not setting pre-conditions upon their expectations of what learners can be achieved, but building the professional capacity to respond to the needs of the moment.

'Particpant A - ...I think some of the things children find difficult certainly I recognise from school that is that when things are difficult 
children feel uncomfortable and then they think something is wrong. Reassuring them that learning is like that..... and that is a positive step towards learning.

An indication of what was learnt in the project was revealed in the way strategies and tactics were referenced in the discussion, often combined with warnings about what limits possibility. Being judgmental as a teacher about pupils and expectations of their potential and abilities is often responsible for limiting pupil achievement.

'Participant $\mathrm{C}-\mathrm{I}$ think the expectations that you have sometimes limits what you end up planning your teaching around. .....the kids shock you by doing something you never expected them to do.'

Over-managing pupils often creates the effect of simplifying achievement goals so that only outcomes that are easily measured are valued and subsequently assessed, whereas in this project, a major benefit -and permission was granted for being able to focus on higher-order educational purposes such as learning how to learn and how to lead others.

'Participant B - We try not just to get the children to be accountable for their own learning but accountable for another's learning as well... I go around saying "how is your partner doing today"? rather than ask them.'

It was clearly stated in Q10 that it is impossible to assess everything taught, particularly higher order learning, emphasis therefore needs to be placed on clarifying the purposes of assessment and using a range of assessment types appropriately.

\section{Values grid results}


Table 3 is a summary of the way in which participants judged the emphasis of their professional roles to have changed in importance as teachers:

\begin{tabular}{|c|c|c|c|c|c|}
\hline \multirow[t]{2}{*}{ The role of the teacher } & \multicolumn{5}{|c|}{$\begin{array}{l}\text { Changes in perceived level of } \\
\text { importance due to project }\end{array}$} \\
\hline & $\begin{array}{l}\text { A lot } \\
\text { more }\end{array}$ & More & $\begin{array}{l}\text { No } \\
\text { change }\end{array}$ & Less & $\begin{array}{l}\text { A lot } \\
\text { less }\end{array}$ \\
\hline 1 Promotion of secure trusting relationships & $\mathrm{C}$ & A B & & & \\
\hline 2 Creating a variety of contexts for learning & A B C & & & & \\
\hline 3 Encouraging learners' risk-taking & & A B C & & & \\
\hline 4 Helping to manage learners emotions & A C & & $\mathrm{B}$ & & \\
\hline 5 Taking risks with learners' learning to encourage high standards & A & B C & & & \\
\hline 6 Encouraging learners' originality and innovation & $\mathrm{B}$ & $\mathrm{C}$ & A & & \\
\hline 7 Being self-critical as a teacher & $\mathrm{C}$ & & A B & & \\
\hline 8 Balancing directed and non-directed approaches & $\mathrm{B}$ & A & $\mathrm{C}$ & & \\
\hline 9 Selecting 'content' for lessons that reflects learners' needs & & $\mathrm{C}$ & A & $\mathrm{B}$ & \\
\hline 10 Scaffolding learners' mental modelling & $\mathrm{C}$ & & A & & \\
\hline 11 Possessing relevant up-to-date knowledge of subject & & & $\mathrm{AC}$ & $\mathrm{B}$ & \\
\hline 12 Possessing relevant up-to-date skills in subject & & & A C & $\mathrm{A}$ & \\
\hline 13 Being personally creative as a teacher & A C & $\mathrm{B}$ & & & \\
\hline 14 Promoting sceptical thinking with learners & $\mathrm{B}$ & $\mathrm{C}$ & & & \\
\hline 15 Encouraging learner's self-expression & A B & & $\mathrm{C}$ & & \\
\hline 16 Promoting and encouraging reflective questioning & $\mathrm{B}$ & $\mathrm{A}$ & $\mathrm{C}$ & & \\
\hline 17 Encouraging learners to challenge assumptions within tasks set & A B & & $\mathrm{C}$ & & \\
\hline
\end{tabular}

Participant self-evaluation of changes in perception about the nature of teaching 
Table 4 summarises the teachers' views about changes in the attitudes of the learners during the project period:

\begin{tabular}{|l|l|l|l|l|l|}
\hline $\begin{array}{l}\text { Attitudes of learners: creating the environment in } \\
\text { classrooms and schools }\end{array}$ & \multicolumn{3}{|l|}{$\begin{array}{l}\text { Changes in perceived level of } \\
\text { importance due to project }\end{array}$} \\
\hline & $\begin{array}{l}\text { A lot } \\
\text { more }\end{array}$ & More & $\begin{array}{l}\text { No } \\
\text { change }\end{array}$ & Less & $\begin{array}{l}\text { A lot } \\
\text { less }\end{array}$ \\
\hline 1 Natural curiosity and reflectiveness of approach to learning & & A B & & & \\
\hline 2 Learners are motivated and are single-mindedness to improve & & & A B C & & \\
\hline $\begin{array}{l}\text { 3 Learners are effective in their exploration of ideas prior to } \\
\text { their action }\end{array}$ & B & C & & A & \\
\hline 4 Self-monitoring and reflexivity is embedded in the learning & & B & A C & & \\
\hline $\begin{array}{l}\text { 5 Learners are able to accommodate support from all sources } \\
\text { within the school; }\end{array}$ & & B C & A & & \\
\hline $\begin{array}{l}\text { 6 Learners are able to accommodate support from external } \\
\text { agents and other learning situations. }\end{array}$ & & B C & A & & \\
\hline
\end{tabular}

\section{Participant response profiles arising from Tables $3 \& 4$}

Overall in Table 3, all participants in categories 1,2,3,5, and 13 indicate a shift upwards in the importance of the category. The centrality of trust, suitable contexts for learning, learner and teacher risk-taking and the teacher being personally creative.

' Particpant A - ..she went off and did a little dance - I never have thought that she would develop that level of competence and creativity in the dance that she showed us - she just did it spontaneously..'

These elements were central in the project where participants often found themselves reacting to situations created by learners. Their own understanding of creativity was important in developed intervention tactics. The focused group discussion emphasised the child-centred universe referring to agency, independence, listening to children and being empathetic.

'One of the strengths of the Body Talk workshops was that all of the adults present were fully involved. This meant that children and adults 
simultaneously experienced creative decision - making and the nervousness, excitement and enjoyment that accompany it.' (Summary report p.5)

In all other categories, some participants identified no change. In Table 4, the only category where all participants admitted a shift upwards in priority was with the promotion of natural curiosity and reflectiveness of approach likely to the vehicle in which interest is captured and skill and knowledge development supported.

\section{Participant A profile}

Categories that represented 'a lot more importance' appeared in a crosssection of categories for this participant covering created appropriate environments, managing learner's needs and responses and also expressing their own personal creativity. This participant was special-needs trained and holds a psychology background. Subject content is identified as less important as was generally developing cognitive capacities. This participant believes in supporting emotional growth and self-esteem resulting in a learner that is more orientated to learning.

'You have got to be empathetic definitely - a kind of social worker'

This participant indicated less change in the priorities concerned with pupil attitudes to learning and unlike both other participants, puts learner planning and preparation as less important. Learner self-expression was highly placed but could be anticipated as this participant also has a dance specialism.

Only one change was identified in Table 4 as having increased in importance - natural curiosity. Working with special needs pupils is essentially pupil- 
centred and this project gave the opportunity for wider exploration of ideas with these pupils.

'...you have really got to try to tap into genuine curiosity.' Less importance was placed on the need for planning prior to action that could result from the effective way pupils engaged with the learning in the workshops and took spontaneous action.

\section{Participant B profile}

This most experienced participant identified 7 categories in Table 3 that increased in importance a lot more as a result of the project. The categories generally concerned the importance of learners thoughtfully challenging ideas and increasing the agency of learners. Categorised as more important were factors concerning building trusting relationships and learner risktaking, but also for teachers having an understanding of what being creative entails. Having experience of 21 years teaching and a senior manager role in a primary school it is possible that these views result from a frustration of working in the primary sector following a period of intense operation within the performativity culture.

'I would say at the moment that we are not measuring it (creativity) very well - IO think the way assessment procedures are set up are so rigid that they don't allow you to paint the full picture.'

The categories that are identified as less importance are concerned with upto-date subject knowledge and selection of lesson content. Reduced importance of these is recognised as the penalty for raised importance of soft-skill and process development and the constructivist-learning environment. This was the only participant who did not recognise a shift in 
emphasis to dealing with learner's emotional needs, but the participant had a background in special needs education and hence prioritised and has the tools to deal with learners in the normal work environment.

' I think the Government is so scared of any subjective data and yet everything you do - the way you interact is personal....'

Table 4 responses reveal the increased attention given to learner attitude development that focuses their own agency in learning and the skills to recognise what and how to learn. Learner planning and preparation skills prior to action is noted as the category of greatest change. This has interesting implications for the nature and type of planning and preparation that teachers are trained to undertake in the English system and how planning ideas are re-enforced through agencies such as OFSTED. This judgment is all the more interesting as Participant A had previously been a local authority adviser. The individualised focus on self-determination and learner motivation is unsurprisingly not recognised as being subject to change.

\footnotetext{
'I think often when you have to stop your lessons in school - they have just found something really difficult - then you stop it. We had some rally rough times in those performances - but they had to come out the other end - they had to carry on - that really helped.'
}

\section{Participant C profile}

This participant categorised 10/16 responses in Table 3 as more or a lot more. Participant $\mathrm{C}$ was also the least experienced teacher with only three years mainstream teaching experience in a secondary school. Promoting 
trust, supporting emotional growth, scaffolding mental modeling and personal creativity were the most highly rated.

'I have a problem now at school with the way we are trying to define success criteria for everything we teach. I think this can be a real constraint. It kind of prevents the open-endedness of creative activities.'

This participant was PE and dance trained and it is easy to recognise why these factors were valued. Areas of no change largely concern subject knowledge and skills that in a secondary setting there is heavy emphasis placed on categories 15, 16 and 17 concerning learner responses to challenges registered no change in priority but interestingly unlike Participants A and B. Yet these factors help to build learner identity that holds the ability to engage with fully in order to understand the world.

Participant $\mathrm{C}$ also re-orientated her values concerned with learner attitude development to a greater extent than Participants A and B profiles (see Table 4).

'I never imagined my girls would respond so well to these activities...it was brilliant.'

With such limited experience this teacher would have been inducted into and learnt how to deal with a secondary school subject to normative accountabilities and therefore unused to personalising learning in quite this way. The two categories indicating no change are likely to be areas with this participant's background that were already priority areas.

\section{Discussion}


The culture of the CARA 2 projects was that of promoting and celebrating creative activity in schools (CapeUK, 2005). Projects that were funded were recognised to have the potential to generate creative activity in classrooms and challenge orthodoxy in classroom methodologies. This project brought together practitioners and learners from different phases and types of school and adopted an action research approach to teacher development to create the climate for learners to actively engage, hence was innovative and outside normal experience. In the focus group interview, Participant A stated -and was subsequently agreed by the other participants:

\footnotetext{
'It is good - we had meetings in the planning process- that is something we are familiar with as teachers - but you don't collaboratively reflect - and then have other professionals - the dancers - reflecting with us - those sessions were really useful'
}

The research examines in a limited way the learning journeys taken by the professionals and focuses mostly on how relationships were built between the each other and the learners and how they thought the project had impacted upon their conceptualisations of their roles as professionals. The impacts upon learners are largely ignored for this research even though through the lenses of the teachers they appear exciting and a worthy extension of the research is to measure the changes in the competences and confidence they developed. In Table 2, Q 6, a strong sense of collaborative working is conveyed - the teachers building up a sense of professional collegiality where they innovate together, face new challenges and deal with the issues and problems that arise. They lost the sense of fear generated through working alone, feeling insecure and inadequate. Motivation for teaching is 
emphasised and the value of being able to engage in collaborative professional learning.

- 'partners recognised and appreciated each others' strengths and areas of expertise;

- an open and honest dialogue was set up in which it was safe to question and challenge each others ideas and approaches;

- there was a shared commitment and sense of responsibility with regards to the project's success;

- there was a real sense of 'learning together' as new ideas emerged;

- being part of a group ensured progression and prevented stagnation.' (Final report)

This can be seen as in contrast with the backcloth of high stakes testing, a performativity culture and a perception of working in a climate of 'state surveillance' described by Craft (2005, p. 128) where teachers feel unable to support each other and have to respond individually to what is demanded of them by higher authority.

\section{Learner responses}

The close focus on the learners and their particular needs became more potent as the project developed. Each workshop resulted in new levels of awareness about the potential and capacities of this particular cohort of learners who carried in some cases severe learning needs. The teachers were 
allowed to observe the powerful social and cultural interactions between the learners, themselves and the creative partners. The ethos of collaboration is clearly illustrated in Table 2, Q11 even centring on how learners are induced into taking care of each other. Managing and changing the social and cultural contexts enabled the strengths of the learners to be built upon and their areas of need to be addressed in non-threatening innovative ways. In the values grid, all of the participants agreed that creating new contexts for learning was a category where their values had adjusted most positively. In Table 3, two of the participants recognised the important role of external agents to the educational experience of learners. Creating a supportive climate was recognised to be crucial to securing effective, empowering learning.

A clear emergent theme from participant responses was that they were surprised and motivated by the positive response of the learners, the rate at which their confidence developed and the way they interacted with each other across the different school cohorts. This resulted in a re-affirmed belief that it is possible for learners to take the lead and that they 'do not have to be controlled at all times'. That their role as teachers is more about creating the environment for learning than delivering content. Also that they as teachers need to have a confident theoretical understanding of the educational contexts in which they want learning to occur. These themes all contributed to a re-aligned relationship between their understanding of teacher professionalism and their sense of identity as teachers. 


\section{Teaching methodologies}

Learners and their needs became the focal point for all discussion and action by the teachers. The core value was constructed around respect for learners and creating the freedom for them as individuals to engage, experiment and learn in a structured and rigorous way. The critical role of the creative partners who as the co-ordinator who discussed teachers and dancers viewing creativity from each other's perspective and in so doing moving towards a shared understanding (Final report).

Feelings of success came from creating the supportive environment for learning together and then seeing children perform beyond expectations. This in turn fed back into the psyche of the participants realising that what had been achieved resulted from a team effort. The participants therefore learnt from each other - both in terms of subject (dance) knowledge and pedagogic knowledge. Participants gained such confidence from this that they were prepared to be self-critical in an open way creating a culture of self-improvement (Table 2). This enhanced personal creativity (identified in Table 3).

The changes in practice associated with the elements identified in Table 3 indicate recognition of the fact that learning is not something solely located in classrooms and controlled by teachers. These participants felt empowered to challenge boundaries; to be resourceful in finding new resources (such as those of the creative partners), new opportunities not clearly quantified in existing professional guidelines. This in turn questions the purposes of defining the nature of teacher professionalism in precise terms if as often 
occurs in current practice. Professionalism defines what cannot happen rather than what can. Risk-taking is a related area rated highly in Table 2, Qs. 3 \& 5 requiring the need to challenge orthodoxy and existing boundaries. This came on the back of relationships with the project group as people, as much as their relationship with them as professionals.

\section{Sustainability}

The evidence from the data indicates that these participants embraced change but were developing the tools through experience to manage it through developing the skills of action research, through developing open and confident relationships with each other, other members of the team and the learners. They indicated a number of areas in which their values had changed and were prepared commit to a project such as this whilst continuing with normal school roles. During the project, non-project classes were benefitting as indicated by Participant B -

\footnotetext{
'We are doing a book project at the moment with the children and they are totally self-sufficient. I have got children working from levels $2 \mathrm{C}$ up to 4A, they are different ages and it works absolutely fine.'
}

Here the teacher can be a genuine mediator of the learning in the classroom and is developing the high level skills necessary to carry out the task noted by Davies (2008). Participants have also been through a period where together they have been developing a theory of learning constructed around their experiences and reflections. This allows them to become transformative agents as they exercise the necessary risks with learners to share power with them without fear of failure and allows any failure to be harnessed for 
purposes of learning. Participant $\mathrm{C}$ noted the limited control teachers have over the curriculum but Participant B said that she thought careful planning on the basis of what she now knows will allow creative interpretation of legal requirements to use the lessons learnt from the project to maximise creative learning opportunities. In the joint report the participants stated:

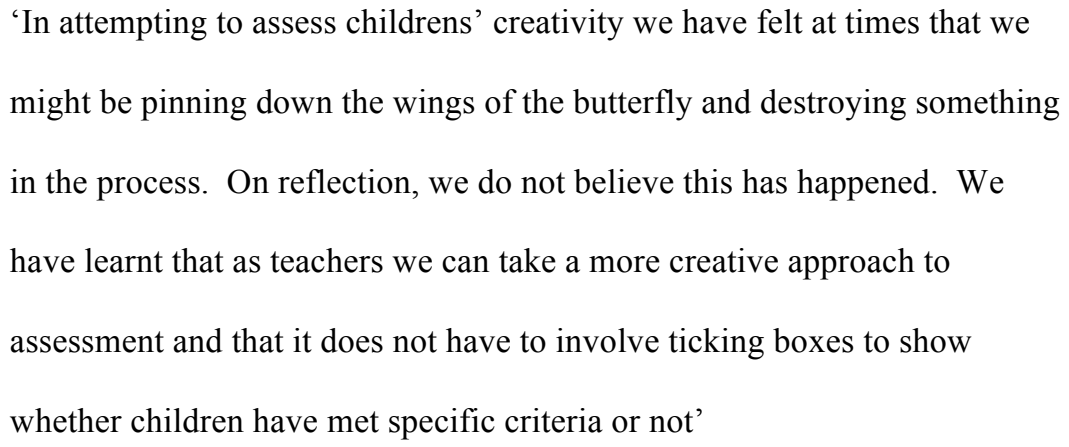

Through the process they had been through they came to believe that reciprocity between teachers and learners had become the most powerful catalyst for learning. Whilst this is no guarantee for permanent shifts in practice, it gives motivation and raises sufficient new questions in the participants' minds to continue to seek new answers and better ways of conducting education.

\section{Conclusions}

Developing new approaches to teaching and learning is likely to involve: constructing and testing new knowledge; holding notions of changeable reality; and working with detail and complexity within a domain. Measurement of this is firstly difficult and secondly of questionable worth and it is through classroom culture that we judge the qualities and attributes 
associated with creativity and generate the opportunities to promote it through teaching and learning.

The boundaries of professionalism were widened as teachers saw themselves as capable of making good educational decisions about their pupils learning and also being trusted to make them. The research recognises how much teachers having positive experiences with learners excites and motivates them. The impact of positive events in teachers' lives as with all people often has the capacity to alleviate negative events - by offering psychological respite and this contributes towards sustainable change.

During the project, the professional identities of the participants evolved as they focused ever more closely on personalised approaches to learning and empowering learners through sharing the responsibility for learning with them. The participants defined themselves much more through what success learners were achieving on a broad front, including the development of confident responses from them, rather than simply test-based achievement. Evans (2008, p. 35) stresses that central to the raising standards and improving society for all, must be professional development for teachers that has educational integrity and genuinely improves educational value. Evans (2008, p. 31) argues that educational reform in the UK sets out to change the professionalism of teachers and has succeeded in doing so, but it has only succeeded in a functional way and achieved limited success in raising standards and achievement in relation to other industrial nations (UNICEF, 2007) with extremely negative consequences for child well-being 
overall. This should not be surprising as in redefining professionalism, Government demands that it controls the fine detail responses that constitute the day-to-day activities in classrooms. Teachers therefore constantly need to update themselves on what their expected response to these situations should be. It is this updating their knowledge of Government approved policy that has comprised 'accepted professional development'. Usually undertaken by approved agencies to ensure consistency in the delivery of accepted policy. Typical of the procedural tools adopted to force school improvement has been school inspection. According to Ehren \& Visscher (2008, p. 224) these have typically enabled schools to make small changes to their procedures but have been ineffective in facilitating the more complex changes associated with building a professional learning community usually required to make a difference.

Professionals in any area clearly need to be regulated and held accountable for their actions, but what is at the heart of good teaching? It is the trust that a learner has in the teacher's ability to prepare him / her for their future world - not the present one. This project was conducted on the basis of trusting teachers' judgments to expose learners to new and innovative situations and to allow them to manage the process in an evolving way hence developing the tools and instincts to turn failure into real learning and opportunity. Trust always involves vulnerability (Frowe, 2008; p. 43) but if the basis for trust is built solidly into the way teachers are trained, opportunities for abrogation of trust are minimised and the discretionary powers given to a professional are amply rewarded. Frowe (p. 52) also 
argues that innovation and experimentation is encouraged by the freedom granted by trust, leading to mutually beneficial opportunities that would be missed in the absence of it. In their proposition for the Fourth Way, Hargreaves \& Shirley (2009) discuss the need to reform education to be relevant and inspiring for the future based upon a democratic and professional path that builds from the bottom. From their 'Six Pillars of Purpose' they cite the need for an inspiring and inclusive vision; students as partners in change and mindful teaching and learning (p. 73). Where teachers are committed to and develop capability of being creative to construct 'deep and broad teaching and learning, that builds powerful, responsible and lively 'professional learning communities(PLC)' in an increasingly self-regulated but not self-absorbed or self-seeking profession' (p. 107). PLC's are generally seen as having effective staff development team approaches and powerful strategies for school reform at their heart and 'community values' and 'shared vision' are crucial to their success. Brighouse (2008) reflects upon the ways in which successive recent UK Governments have spent most time and energy engineering ways to effect and control entry into the profession and have largely ignored the development needs of the existing teaching force. Trust has been factored out of the bank of qualities a professional holds based upon their knowledge, skills and capabilities (Frowe, 2008), but must be re-established. The project however has identified a set of values and procedures that can enhance the performance of pupils and the performance, values and motivation of teachers consistent with building a PLC. The opportunity for the teachers to be creative in this project has resulted in them fashioning different values on 
which to construct practice, major increases in their confidence to make decisions on the basis of learner needs and a great increase in enthusiasm to develop teacher responses that result in high learner achievement.

The shift in values does not guarantee that progress will be sustainable as this depends upon whole culture change within their institutions. At least however during the projects the teachers developed skills and some confidence as reformers within the context of a PLC and are more likely to initiate and / or support reform agendas that have creative learning at its heart.

\section{References}

Aubusson, P., Steele, F., Dinham, S. \& Brady, L. (2008). Action learning in teacher learning community formation: informative or transformative? Teacher Development, 11 (2), 133-148.

Barak, M, \& Doppelt, Y. (1998). Promoting Creative Thinking Within Technology Education. Paper presented at the International Workshop Seminar for Scholars in Technology Education, Washington, DC.

Beck, J. (2008) Governmental professionalism: re-professionalising or deprofessionalising teachers in England. British Journal of Educational Studies, 56 (2), 119-143.

British Educational Research Association (2004) Revised ethical guidelines for educational research. Retrieved June 12, 2009, from BERA website: http://www.bera.ac.uk/files/guidelines/ethica1.pdf 
Bosher, M. \& Hazlewood, P. (2009) Leading the leaders for the future. UK: Continuum.

Brighouse, T. (2008) Putting professional development centre stage. Oxford Review of Education, 34 (3), 313-323.

CapeUK (2005) CARA - Building creative futures. Retrieved August 1, 2010, from CapeUK website: http://www.capeuk.org/capeukresources/building-creative-futures.html CapeUK (2006) CARA2; the handbook. England: Arts Council. Craft, A. (2005) Creativity in schools: tensions and dilemmas. Abingdon, USA \& Canada: Routledge.

Cresswell, J. (1998) Qualitative inquiry and research design: choosing amongst the five traditions. California: Sage Publications.

Davies T. (2006) Creative teaching and learning in Europe: promoting a new paradigm. The Curriculum Journal. 17(1), 37 - 57.

Davies, T. (2002). Creativity: its contribution to design and technology education. Unpublished Ph. D Thesis. Reading: University of Reading. De Bono, E. (2010) The 'six thinking hats' for schools. Retrieved December 6, 2010, from DeBono website: http://www.edwdebono.com/shcd1.htm De Bono, E. (1992) Serious creativity. London: Harper Collins Business. De Bono, E (1985) Six thinking Hats. England: Little, Brown \& Company. Department for Education and Employment (1999). All our futures: creativity culture and education. Suffolk: DFEE publications. Ehren, M. C. M. \& Visscher, A. J. (2008). The relationship between school inspections, school characteristics and school improvement. British Journal of Educational Studies, 56 (2), 205-227. 
Evans, L. (2008). Professionalism, professionality and the development of education professionals. British Journal of Educational Studies, (56)1, 2038.

Feldman, D., Csikztenmihayli, M. \& Gardner, H. (1995) Changing the world: a framework for the study of creativity. USA: Praeger.

Frowe, I. (2005). Professional trust. British Journal of Educational Studies. (53)1, 34-53.

Fryer, M. (1996) Creative teaching and learning. London: Paul Chapman. Handy, C. (1995) The empty raincoat. Reading: Arrow Books Ltd.. Hargreaves, A. \& Shirley, D. (2009) The Fourth Way: the inspiring future for educational change. California: Corwin.

Goodson, I. \& Hargreaves, A. (Eds.) (1996) Teacher's Professional Lives. (New Prospect Series). Abingdon: Routledge.

Hoyle, E. (1975) Professionality, professionalism and control in teaching. In: Houghton, V. et al. (Eds) Management in Education: the management of organisations and individuals. London: Ward Lock Educational in association with Open University Press.

Hoyle, E. (Ed)(1981) Managerial Processes in Schools. Milton Keynes: Open University Press.

Hoyle, E. \& John, P. D. (1995) Professional knowledge and professional practice. London: Cassell. Jeffrey, B. \& Craft, A. (2004) Teaching creatively and teaching for creativity: distinctions and relationship. Journal of Educational Studies, 30(1), 77-87.

LeBoeuf, M. (1994) Creative thinking. London: Judy Piatkus. 
Newby, P. (2010) Research methods for education. England: Pearson.

Rogers, M. \& Fasciato, M (2005) Can creativity be assessed? Conference

Paper, British Educational Research Association conference Sepotember 1417, 2005; University of Glamorgan. Retrieved October 6, 2010, from BERA website: http://www.leeds.ac.uk/educol/documents/150029.htm Royal Society of Arts (2010) Opening Minds. Retrieved December 6, 2010 from RSA website: http://www.thersa.org/projects/opening-minds

Seltzer, K. \& Bentley, T. (1999) The creative age: knowledge and skills for the new economy. London: DEMOS.

Shoulksmith, G. (1970) Intelligence, creativity and cognitive style. London: Batsford.

Smyth, J. (2007) Teacher development against the policy reform grain: an argument for recapturing relationships in teaching and learning. Teacher development, (11)2, 221-236.

Torrance, E., P. (1962) Torrance tests of creative thinking. Indiana: Bensenville.

Woods, P. (2002) Teaching and learning in the new millennium.

UNICEF (2007). Report Card 7, child poverty in perspective: An overview of Child Well-being in Rich Countries. Retrieved November 11, 2010, from UNICEF website: http://www.unicef-irc.org/publications/494 Yin, R.K. (1989) Case study research: design and methods (revised edition). (Applied Social Research Methods Series Vol. 5). CA: Sage Publications. 